\title{
Ecosystem Services of the Eco-Engineers: The Earthworms
}

\author{
Mansi Ramesh Das, Amruta Chandrakant Nimbalkar*, Samiksha Sunil Pisal and \\ Vitthalrao B. Khyade
}

\begin{abstract}
Science Association, Shardabai Pawar Mahila Mahavidyalaya, Shardanagar Tal. Baramati Dist. Pune - 413115, India
\end{abstract}

*Corresponding author

\begin{tabular}{|l|}
\hline K e y w o r d s \\
Vermicomposting, \\
$\begin{array}{l}\text { Earthworm, Diversity, } \\
\text { Ecosystem services, } \\
\text { Threat }\end{array}$ \\
\hline Article Info \\
\hline $\begin{array}{l}\text { Accepted: } \\
\text { 10 September } 2018 \\
\text { Available Online: } \\
\text { 10 October } 2018\end{array}$ \\
\hline
\end{tabular}

\section{Introduction}

Earthworms can play a variety of important roles in agroecosystems. Their feeding and burrowing activities incorporate organic residues and amendments into the soil, enhancing decomposition, humus formation, nutrient cycling, and soil structural development (Mackay and Kladivko, 1985; Kladivko et al., 1986). Earthworm burrows persist as macropores which provide low resistance channels for root growth, water infiltration, and gas exchange (Kladivko and
Although most earthworms live at or under the surface of the soil, other factors influence their choice of habitat. Two key factors are climate and vegetation. Earthworms tend not to live in exceptionally dry or cold places. The earthworms live in indigenous forests and tussock grassland, while introduced species are most commonly found in cultivated soils such as pasture, croplands and lawns. A more specific way to describe where earthworms live is their niche - the position of the species within its habitat. A species' niche includes both its physical location and the role it plays within the environment. By occupying a specific niche, earthworms make use of conditions that are best suited to their survival. Alhough all earthworms have common characteristics, features like size, pigmentation colour) and quickness of movement reflect which niche different species occupy. Soil-dwelling earthworms fall into three main niche groupings: compost and soil-surface dwellers (epigeic), top-soil dwellers (endogeic) and deep-burrowing subsoil dwellers (anecic). The present attempt intends to communicate the importance of earthworm diversity conservation. Development of conservation management to prevent earthworm diversity decline should be done wisely and involve all stakeholders. 
Biodiversity is classified into above-ground biodiversity and below-ground biodiversity (soil biodiversity) that mutually interact (Wardle, 2002; Wardle et al., 2004). Functioning of terrestrial ecosystems greatly depends on below-ground biodiversity. Soil biodiversity is vital to humans as it supports a wide range of ecosystem processes, functions, and services (Costanza et al., 1997; Blouin et al., 2013; Skubala, 2013; Jouquet et al., 2014). However, the importance of below-ground biodiversity has often been ignored or undervalued (Secretariat of the Convention on Biological Diversity, 2010). Soil biodiversity in many areas worldwide has already been declining (Jeffery and Gardi, 2010). Furthermore, biodiversity loss results in the decline of ecosystem resilience. When elements of biodiversity are lost or threatened, ecosystem services degrade (Black et al., 2003). Ecosystems with heterogeneous biodiversity tend to be more stable, whereas those with homogeneous biodiversity are often more vulnerable to environmental stress (Hunter Jr., 1999). Healthy soil biodiversity provides a number of natural services that are useful to human being.

Ecosystem services are defined as contributions of ecosystem structure and functions, in combination with other inputs, to human well-being. Essentially, these are services provided by biodiversity that link the functioning of ecosystems to their benefit extended to humans. Ecosystem processes are the changes or reactions occurring in an ecosystem, such as, for instance, biophysical processes (decomposition, production, nutrient cycling, energy, and nutrient fluxes) (Crossman et al., 2013). Ecosystem functions occupy an intermediate position between ecosystems processes and services. Ecosystem function can be defined as the capacity of ecosystem to provide goods and services that satisfy human needs, both directly and indirectly (de Groot et al., 2002); these functions affect ecosystem services (Jouquet et al., 2014). Ecosystems services were estimated to account to up to U.S. \$33 trillion dollars per year of human capital equivalent. Soil biota contributes to approximately $38 \%$ of this amount (Skubala, 2013). The rapid growth of human population leads to increased pressure on soil. Anthropogenic activities accelerate the loss of biodiversity and ecosystem services in soil. Currently, approximately $60 \%$ of ecosystem services is degraded because soil is not used in a sustainable manner (Skubala, 2013).

Earthworms represent an important soil faunal group that is distributed worldwide. Earthworm populations contribute to approximately $40-90 \%$ of soil macrofaunal biomass and $8 \%$ of total soil biomass in many ecosystems (Sinha et al., 2013). However, in intensively cultivated annual crops earthworms have lower contribution to total soil biomass (Fragoso et al., 1999; Tondoh et al., 2007; Blouin et al., 2013). Earthworms are the most valuable animals that influence the functioning of soil ecosystems (Hendrix and Bohlen 2002; Gonzales et al., 2006). Earthworms increase soil bulk density, pore size, water infiltration rate, soil water content, and water holding capacity. They also increase litter decomposition, soil organic matter dynamics, nutrient cycles, promote plant growth and reduce some soil-borne diseases (Brusaard, 1997; Chandran et al., 2012; Elmer, 2012). Earthworms produce organomineral biogenic structures (Lavelle, 2000), and influence gaseous composition of the atmosphere (Kibblewhite et al., 2008). Earthworms are also involved in restoring ecosystem services via direct and indirect mechanisms (Jouquet et al., 2014), especially in the situations when soil is degraded or land is under rehabilitation after mining (Boyer and Wratten, 2010). Earthworms represent an essential component of soil nutrient cycling (Lavelle and Spain, 2001). They maintain 
good soil health through the comminution of organic debris, enhance microbial activity, and contribute to the increase of nutrient availability in soil and mineral absorption by plants. Burrowing and grazing activity of earthworms modifies the soil structure and its capacity to absorb water. These advantages increase crop productivity. Earthworms represent a unique indicator of soil health (Science for Environment Policy, 2009; Elmer, 2012), and a good bio-indicator of degraded land due to anthropogenic activities (Tondoh et al., 2007). Earthworm diversity is a key determinant of ecosystem stability that is responsible for the provision of many ecosystem services (Eisenhauer and Schädler 2011; Blouin et al., 2013).

Earthworm communities consist of many different species, and each plays a unique role in soil processes. To understand the function of earthworms in soil ecosystems, first the species valuable to ecosystem services should be identified. Research on earthworm species diversity has been carried out, but only in a limited number of geographical regions. According to a previous study, less than 50\% of earthworm species in the world have been described (Brown et al., 2003). The knowledge of earthworm species diversity is still limited in many countries (Brown et al., 2006), and especially in tropics (Suthar, 2011; Chandran et al., 2012). Moreover, earthworm diversity studies have mostly focused on taxonomy and have not evaluated the association with ecosystem services. Soil systems provide an excellent basis to investigate the relationship between earthworm diversity and ecosystem functioning (Lavelle, 2000). A clear understanding of the relationships between earthworm diversity and ecosystem services is required to evaluate the influence of anthropogenic activities on ecosystems, and to develop management strategies aiming to preserve earthworm diversity.
Five forces are considered to accelerate the decline of earthworm diversity:

Soil degradation and habitat loss,

Climate change,

Excessive nutrient and other forms of contamination load,

Over-exploitation and unsustainable management of soil, and

Invasive species (Moore, 2005; Secretariat of the Convention on Biological Diversity, 2010).

Global increase in human population and demand for resources has led conversion of forests to agricultural or urban land worldwide. This largely contributes to the decrease and loss of earthworm biodiversity. Habitat loss and soil degradation, caused by agricultural activities and unsustainable forest management, represent the greatest pressure on earthworm diversity. Some researchers have reported that earthworm diversity has been reduced, and some native species have been lost, because of forest conversion to agriculture and presence of invasive species. Such species loss results in negative impacts on ecosystem services (Dewi et al., 2006; Loss et al., 2012; Hairiah et al., 2014).

Soils represent the main habitat for earthworms. However, many soils undergo degradation processes (Lavelle et al., 2006; Lavelle, 2009), thereby endangering earthworm diversity. Soil degradation is one of the most dangerous threats to earthworm diversity in this century that should receive more attention around the world (Skubala, 2013). Understanding how earthworm species adapt to disturbances and survive in agriculture soils can help to develop strategies to earthworm biodiversity conservation. 
Moreover, the importance of earthworm diversity to ecosystem services and human well-being needs to be communicated to different stakeholders, including farmers. Local ecological knowledge can be used to facilitate the communication between farmers and scientists (Zúñiga et al., 2013).

\section{Ecosystem services availed by the earthworm}

Earthworms are soil inhabitants. However, different earthworm species have different feeding and living preferences, as well as burrowing behaviors. Hence, earthworms species show different ecological functions. They can be classified into epigeic, endogeic, and anecic species (Fragoso and Lavelle, 1995; Fragoso et al., 1997; Brusaard, 1997). Epigeic earthworms eat and live on rich litter surface layer and do not form burrows; they have small size body $(5-15 \mathrm{~cm}$ body length at maturity), and bright color (Jones, 2003). Epigeic species play an important role in litter comminution and decomposition of organic material at the soil surface that increase nutrient transformation and stimulate activity of microorganisms. Anecic species live in subvertical burrows in the mineral soil, feed on fresh litter from surface soil and bring it into the soil profile (Fragoso et al., 1997); these worms are colored on the dorsal side and often have a large size body $(15-20 \mathrm{~cm})$ (Keith and Robinson, 2012). Anecic earthworms can burrow into the deeper layers of the soil, and reach depth of 1-2 $\mathrm{m}$. Their feeding activity modifies the soil structure through the creation of vertical burrows and increases macroporosities, aeration, and water infiltration into the deeper soil. Anecic burrow entrances called "midden" that are surrounded by a mound of cast material and usually crowned with fragmented plant litter. Anecic earthworms also affect litter breakdown rate and nutrient cycling by combining surface litter into the soil profile. Endogeic earthworms are living and feeding in the soil, so they are considered soil feeders. They play a key role in soil aggregate formation. Endogeic species have a body size of approximately $5-10 \mathrm{~cm}$ and are usually not pigmented. Their activity creates a network of horizontal branching burrows, which increase porosity, and release nutrients from their feces (Jones, 2003). Inoculation of endogeic earthworm Pontoscolex corethrurus in agroforestry mesocosms increased mean weight diameter, $\mathrm{C}$ and $\mathrm{N}$ storage in large macro-aggregates $(>2000 \mu \mathrm{m})$ (Keith and Robinson, 2012). Soil ecosystems inhabited by epigeic, endogeic, and anecic earthworms have better physical, chemical, and biological properties than other ecosystems inhabited by only one or two levels of earthworm functional groups. Moreover, the presence of different earthworm functional groups in soil has a positive effect on ecosystem services. The summary of relationships between earthworm functional groups, soil processes and ecosystems services are shown in Figure 1.

In addition to the earthworm classification based on functional groups, earthworms can be classified based on biogeography, into native species and exotic species. Native species of earthworms evolve in the given site or region (Fragoso et al., 1999). Such earthworm species usually live in one region, in contrast to species that have been introduced by human activity. Exotic or introduced earthworm species are those earthworm species that have been transported to areas where these species do not live naturally, either on purpose or by accident. Most research has focused on this group of earthworms.

Earthworm life is influenced by the availability of suitable food, soil moisture, soil temperature, oxygen exchange, soil texture, soil $\mathrm{pH}$, and presence of predators (Edward 
and Lofty, 1977; Lee, 1985). Earthworms like moist soil, because the water protection mechanisms in their bodies are not well developed. Respiration rate depends on the gas diffusion through the body wall, which must always be moist. Earthworms can survive in a range of soil temperatures varying between $0^{\circ} \mathrm{C}$ and $35^{\circ} \mathrm{C}$ (Lee, 1985). The optimum soil water content varies considerably depending on the species and ecological group earthworm belongs to, that can differ even within the same species, depending on its ability to adapt to local environmental conditions (Lee, 1985). Earthworms are most active in moist soil conditions (Lee, 1985; Lavelle and Spain, 2001). The earthworm community structure is controlled by the nutrient content of soil and the amount of seasonal rainfall (Fragoso and Lavelle, 1995).

The main food source for earthworms is decaying organic waste (Lee, 1985). Earthworms prefer decomposed organic food larger than $50 \mu \mathrm{m}$ in size (Lavelle et al., 2001). Because of the limited movement capability, earthworms like to live close to source of the food source. Population density and distribution of earthworms in forest ecosystems is strongly influenced by the quantity, quality, and timing of litter inputs to the soil system. The high content of polyphenols and other secondary compounds in litter affects the density of earthworms in tropical forests (Fragoso and Lavelle, 1995). Epigeic earthworms prefer high-quality litter soil layer (Tian, 1992; Lavelle and Spain, 2001). Earthworm communities are also influenced by biological processes occurring within the soil environment. Earthworms develop various interactions with microflora (bacteria, fungi), microfauna (protozoa and nematodes), and other macrofauna groups (ants in particular) (Wardle, 2002). Digestion in earthworms is mediated by the enzyme mixture produced by the intestinal wall, and the microflora and microfauna in earthworms guts (Lavelle and Spain, 2001). Earthworm life is also affected by predators, and especially birds (Lee, 1985). Ecosystem services provided by earthworms relate to the effects of earthworm activity on soil systems (Moreira et al., 2008). Earthworms play an important role in soil ecosystem functioning and human welfare (Hendrix and Bohlen, 2002; Gonzales et al., 2006; Ernst and Emmerling, 2009; Science for Environment Policy, 2009). Earthworm diversity plays an important role in agricultural systems and is an integral part of soil health and fertility. Earthworms consume decomposable organic matter and break it down into smaller pieces providing food to almost all soil microorganisms. Their excrements or "casting" supports highly diverse microbial communities, including beneficial fungi and bacteria (Elmer, 2012). As a result of microbial activity, availability of nutrients to plants also enhances. Earthworms also provide benefits to farmers. Earthworms contribute to the improvement of plant resistance to pests and indirectly suppress soil-borne diseases. As a result, crop productivity improves (Ernst and Emmerling, 2009).

Earthworms have been called "ecosystem engineers." They are capable of modifying their physical environment by mixing soil layers from the bottom to the top and vice versa incorporating organic matter into the soil and producing biogenic structures. This way, earthworms change the structure of the soil. Different types of earthworms' functional groups can create horizontal and vertical tunnels, which can be quite deep in soil. These tunnels form pores that facilitate oxygen and carbon dioxide exchange, and allow water penetration into the soil. Thus, water, gas and solute transfer processes and soil water holding capacity improve (Capowiez et al., 2001). Earthworms' burrows serve as soil macro-porosities (Lal, 1991; Brusaard et al., 
1993; Jimenez et al., 1998; Stott et al., 1999; Lavelle et al., 2001). Soil porosity is crucial property because it determines: (1) rate of water infiltration, (2) water holding capacity, (3) the drainage of water excess, (4) soil moisture, and (5) the exchange rate of $\mathrm{CO}_{2}$ from soil to atmosphere and vice versa (Wolf and Snyder, 2003). The disruption of earthworm diversity impedes water infiltration into the soil thus resulting in increased surface run-off, erosion, flooding, and drought.

Earthworm casts (earthworms' feces) are also crucial to the structure of soils. Earthworm activity has a positive impact on the formation of soil structure, through the improvement of infiltration rate, water absorption, and soil resistance against the erosive of rainfall and surface run-off (Glinski and Lipiec, 1990; Stott et al., 1999). Earthworms make continuous channels from the soil surface to the deeper layers, so that water can infiltrate quickly into the subsoil. Therefore, the soil with higher earthworm activity has better infiltration rate than soil without or with small earthworm community. Hence, earthworm activity reduces the risks of run-off and water logging.

In addition to these indirect advantages, earthworms also directly benefit humans, being for example a food source for fish (and used as a fish bait), and being part of vermicomposting. Some Amerindian communities in South America utilize earthworm as a source of seasonal food and an essential source of protein in their diet (Keith and Robinson, 2012). Earthworms contribute up to $€ 723$ million per year in terms of the livestock product value (Bullock et al., 2008). Earthworms, like all other organisms, have certain advantages and disadvantages. Some species of earthworms were reported to have adverse impacts on soil structure (Lal, 1991; Blanchart et al., 1999). Small-sized endogeic earthworms, a "de-compacting species," eat castings produced by large-sized endogeic earthworms (compacting species), so that the organic matter content of the casting decreased. Casting with lower organic matter will be broken easily by raindrops, resulting the compacted soil. Fresh earthworm casting is soft and fragile, and vulnerable to raindrops, but it becomes harder, and more resistant to water and wind erosion with time. Effect of compacting species on soil structure is strongly influenced by the presence of organic debris on the soil surface. Blanchart et al., (1999) reported that activity of Pontoscolex corethrurus (compacting species) in agroecosystems with low soil organic matter in Yurimaguas (Peru) leads to hardening of soil surface that inhibits the infiltration. However, in the soil with high organic matter content or soil mulched with legumes, earthworms enhance soil macro-aggregate development. Lavelle (2000) also reported that $P$. corethrurus invaded a pasture in Central Amazonia, and produced an excessive amount of unstable large cast. This cast formed $5 \mathrm{~cm}$ impermeable crust inhibiting plant growth. Soils with low organic matter and low earthworm diversity and abundance s tend to be more sensitive to erosion than soils with high earthworm population and diversity (Lal, 1991). Management of soil organic matter is keys factor affecting the ecosystem services performed by earthworms.

Earthworms play an important role in determining the greenhouse-gas balance of soils worldwide. Whether earthworms represent a "sink" or "source" of greenhouse gas remains highly debated. Earthworms cast is stable soil aggregate, is recognized as a "sink". It stimulates carbon sequestration and enhances long-term protection of $\mathrm{C}$ in soil. However, earthworms can accelerate the decomposition of $\mathrm{C}$ by microorganisms in the soil and thus enhance $\mathrm{CO}_{2}$ emission or as "source" of greenhouse gas (Simek and Pizl 2010). Earthworm gut is ideal environment for 
denitrifying bacteria as it is anaerobic microsite enriched by available carbon, nitrogen, with favorable moisture level, essential for stimulating activity of denitrifiers and high potential to increase $\mathrm{N}_{2} \mathrm{O}$ emission. Earthworms activity in fertilized grasslands enhances grass $\mathrm{N}$ uptake. However, earthworms, and epigeic earthworm species (Lumbricus rubellus) in particular, may also have side effects in ecosystems, and increase $\mathrm{N}_{2} \mathrm{O}$ emissions by $10 \%$ (Lubbers et al., 2011, Lubbers et al., 2013). Based on the metaanalysis using 237 observations of 57 articles published on the ISI-Web of Science between 1990 and 2011, it can be concluded that earthworms increased $33 \%$ and $42 \%$ of $\mathrm{CO}_{2}$ and $\mathrm{N}_{2} \mathrm{O}$ emissions, respectively. These effects depend on some controlling factors, such as earthworm functional groups, population size, experimental period, experiment type, nutrient input, soil organic matter content, $\mathrm{C} / \mathrm{N}$ ratio of soil, and type of ecosystem. Over a longer period (> 30 days), earthworms tend to increase $\mathrm{N}_{2} \mathrm{O}$ emissions, but decrease $\mathrm{CO}_{2}$ emission. Increase of $\mathrm{N}_{2} \mathrm{O}$ emissions by earthworms correlates to the increase of organic $\mathrm{C}$ input as well as to the height of soil organic matter layer having low $\mathrm{C} / \mathrm{N}$ ratio (Lubbers et al., 2013). This conclusion was mainly derived based on laboratory experiments and only one article based on field experiments. Moreover, most experiments can only be conducted during less than 200 days. Hence, the effect of earthworms on greenhouse gas balance is still unclear and needs further understanding. The use of biochar in agricultural practices potentially reduces $\mathrm{N}_{2} \mathrm{O}$ emissions produced by earthworms (Asuming-Brempong and Nyalemegbe, 2014). Biochar or charcoal has a porous physical structure, and thus increases oxygen diffusion into the soil and creates aerobic conditions providing a suitable habitat for aerobic soil microorganisms, and potentially reducing the activity of anaerobic denitrifying bacteria. The polycyclic aromatic structure of biochar makes it chemically and biologically stable, allowing it to persist in soil for centuries. Biochar decreases $\mathrm{N}_{2} \mathrm{O}$ emissions since $\mathrm{N}_{2} \mathrm{O}$ emissions are enhanced by high soil organic matter content. Endogeic earthworms, $P$. corethrurus, can grind the biochar and reject it in their casts, which affect biochar distribution in the soil profile. Agricultural management, such as tillage and fertilization with $\mathrm{N}$ fertilizers in particular, plays a significant role in greenhouse gas emission by influencing soil microenvironment (Plaza-Bonilla et al., 2014). Earthworms and biochar application on soil is one of the best technique to improve soil fertility and health (Asuming-Brempong and Nyalemegbe, 2014). The best technology for sustainable management of land and water resources should maintain and protect earthworm abundance and diversity (Blanchart et al., 1999).

\section{Earthworm diversity under threat}

There are thousands of earthworms species with different biogeography. They have different morphological characteristics, although some of these characteristics are difficult to determine by naked eye. Earthworm species can be identified based on three complementary approaches: taxonomy, biogeography, and ecological functional groups. Each identification method has disadvantages. Therefore, identification of earthworm species should be done using more than one method. A taxonomic approach implies studying earthworm diversity based on the number and identity of different species (species richness), regardless of their ecological role. Taxonomic identity can be determined using conventional methods (observing internal and external morphological characteristics), or by advanced molecular genetics and genomic analysis techniques (Dupon, 2009; Chang and James, 2011). However, molecular techniques have 
been rarely applied in earthworm research (Dupon, 2009). The disadvantage of identification based on external morphological characteristics is that this way immature earthworm cannot be identified. However, identification based on internal morphological characteristics is quite difficult, especially for beginners. Molecular methods are more promising but involve high costs, and not affordable to everyone. Systematics of earthworms still faces many problems and is not complete (Fragoso et al., 1999; Jones, 2003). General identification keys for tropical and subtropical earthworm species are not available and still need to be developed. Currently, there are only few professional taxonomists in the world. Hence basic training on earthworm species identification has to be undertaken by new taxonomists (Brown et al., 2013). The difficulties in identifying earthworm species can inhibit researcher's interest to become an earthworm taxonomy expert.

Based on the taxonomic identification, earthworms belong to phylum Annelida, subphylum Clitellata, and class Oligochaeta that consists of 20 families, 693 genera, and more than 6000 species. Currently, 3627 species have been described (Giller et al., 1997; Fragoso et al., 1997; Lavelle and Spain, 2001). It was estimated that less than $50 \%$ of species exist worldwide (Fragoso et al., 1997) and only a few dozen have been studied extensively (Brown et al., 2003). Earthworm species are found mainly in tropics, but most of the tropical regions, such as Southeast Asia, Africa, and South America have not been widely surveyed for earthworm diversity (Jones, 2003). In Indonesia, the research on earthworm diversity is still limited and receives little attention. Despite the high importance of earthworms that were introduced in Indonesia by Darwin in 1938 and many ecological researches in the following years, more research on ecosystems services provided by earthworms is still needed (Brown et al., 2003). Identification of earthworms based on ecological functional groups is an important goal in soil ecology (Keith and Robinson, 2012), and a big challenge for earthworms taxonomists (Giller et al., 1997).

Patterns of earthworm distribution and species richness were described to be directly related to biogeography, local microclimate and human activities (Suthar, 2011). Earthworm species of family Megascolecidae were found in many tropical regions in East and Southeast Asia, and Australia (Edward and Lofty, 1977; Lee, 1985; Jones, 2003; Fragoso and Csuzdi, 2004). Species from family Glossoscolecidae are widespread in the regions of Central America, South and North, while species of family Ocnerodrilidae family are mainly found in India, Central and South America, and Africa. Earthworm species of family Acanthodrilidae are commonly found in India, Burma, New Zealand, and Australia (Fragoso and Csuzdi, 2004).

Why is it essential to study the earthworm diversity? Earthworms represent an important group of soil macrofauna that provides ecosystem services for human well-being. At the same time, earthworms are very sensitive to anthropogenic activities. Earthworm diversity is important to study because the different ecological groups of earthworms play important role in soil processes and ecosystem services. Different species of earthworms are also characterized by different levels of sensitivity to habitat disruption, and are good indicators of land management practices. Estimation of earthworm species richness can help determine the redundancies and keystone species in ecosystem processes. Different earthworm species provide a various functions in different soil layers (Bullock et $a l ., 2008)$. Earthworm diversity is clearly can be used as an estimate of ecosystem services 
(Keith and Robinson, 2012). One more important factor affecting earthworm diversity is environment variability, such as the amount and quality of nutrients and energy sources, seasonal changes, spatial differences in soil and, climate variability, and biotic interactions within the community (Breure, 2004). Soil management in agricultural ecosystems strongly influences earthworm diversity. Different management practices affect the habitat quality and the availability of substrate to earthworms, hence resulting the change in abundance and diversity of earthworms. Intensive soil tillage drastically reduces the earthworm populations, especially in areas where the land has been conversed to monoculture (Bullock et al., 2008). Habitat loss and soil degradation, caused by agriculture and unsustainable forest management create the biggest pressure on earthworm diversity. Some researchers have reported cases of earthworm diversity decrease and loss of native species as a result of forest conversion to agriculture. Forest conversion also increases invasive species domination that has a negative impact on ecosystem services (Dewi et al., 2006; Loss et al., 2012; Hairiah et al., 2014).

Earthworms are sensitive to land use change, ecosystem perturbations, and rehabilitation (Tondoh et al., 2007). Human activities represent an important factor causing reduction of earthworm diversity. Global increase in human population and high demand for resources has led to the conversion of forests to agricultural land. Intensified agricultural management can lead to the decrease or loss of earthworm biodiversity. The USDA Forest Services International Programs reported that every year the world loses 14.6 million hectares (ha) of forest that is converted to agricultural or residential land. Although parts of forests have been used as estates, reforestation and natural forest extension, the world still loses 9.6 million ha of forest per year. Furthermore, the greatest conversion rates in the world are happening in tropics (USDA Forest Service International Programs, 2014). Forest conversion to agricultural and other types of land use leads to disruption of taxonomic and functional diversity, and loss of native earthworm species (Rao, 2013). There is a strong correlation between an increase in land use intensity and decrease in earthworm diversity. Forest conversion to coffee plantations and other agricultural land in Sumberjaya (West Lampung, Indonesia) led to reduction or loss of epigeic native earthworm species, such as Metaphire javanica. Subsequently, the population of small bodysize endogeic-exotic earthworm species such as $P$. corethrurus increased but did not affect the population abundance (Table 1). Native species are more sensitive to land-use change than exotic species (Dewi et al., 2007). Previous studies have also shown that the body size of earthworms tends to be smaller in areas with more intensive land management (Figure 2) (Susilo et al., 2009). Earthworm abundance is higher in areas with more intensive management than in areas with less intensive management. This is especially true in areas with higher plant rotation and larger waste harvests left in the soil (Bullock et al., 2008). Similarly, the forest conversion to intensified agricultural land in Ivory Coast resulted in potential increase in relative abundance and biomass of earthworm species, particularly in areas with medium level intensification agriculture, as reported by Tondoh et al., (2007). These researchers found that some earthworms species were highly sensitive to land use changes, i.e., Dichogaster saliens Beddard 1893, Hyperiodrilus africanus Beddard 1891, Millsonia omodeoi Sims 1986, Dichogaster baeri Sciacchitano 1952, Dichogaster ehrhardti Michaelsen 1898, Agastrodrilus sp., Stuhlmannia palustris Omodeo and Vaillaud 1967 and, to some extent, Millsonia sp. (Tondoh et al., 2007). 


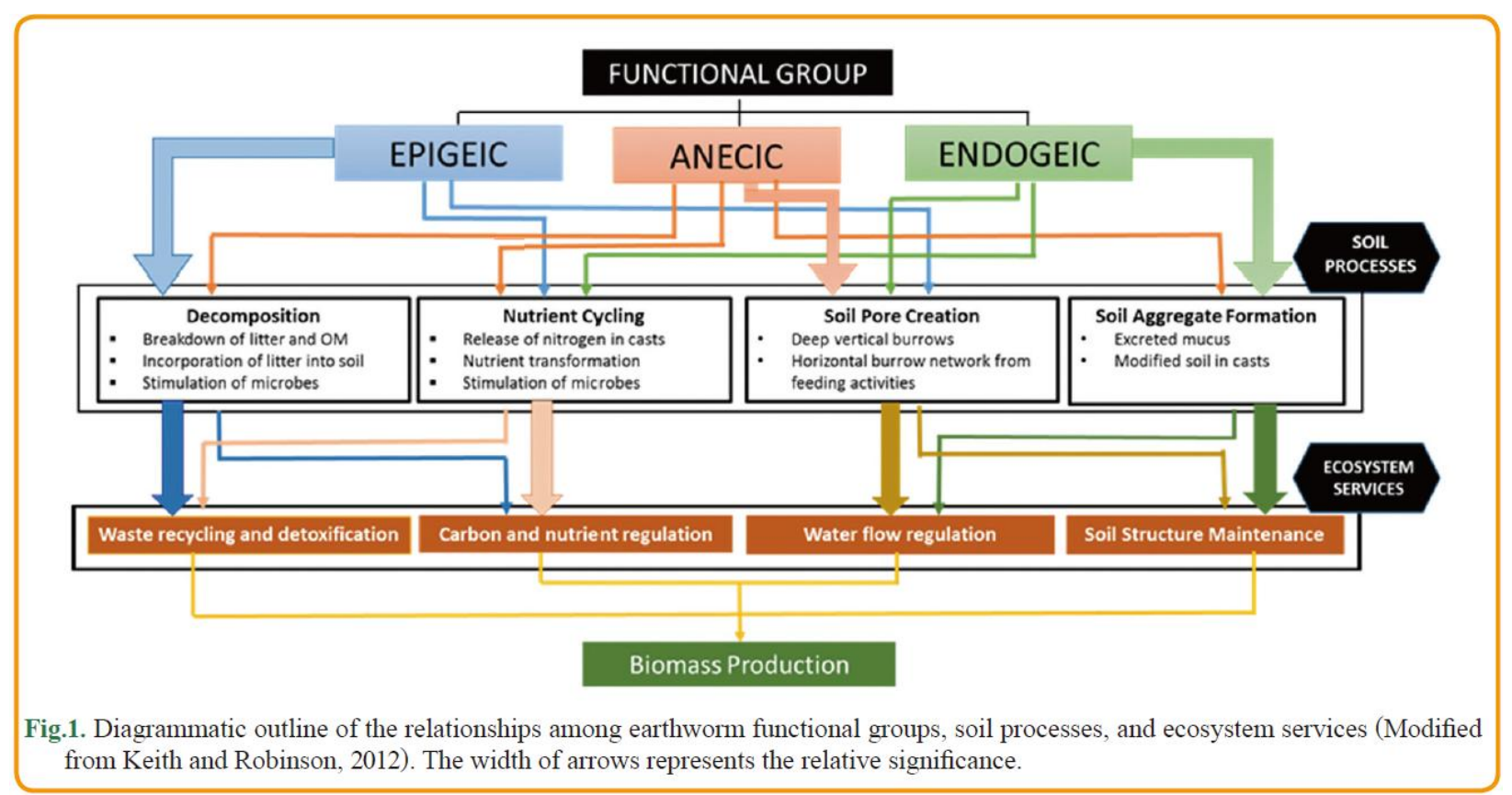

http://www.agrsci.jp/ras/article/view/13/27

\section{Ecological aspects of earthworm}

Earthworm species can be classed in one of three morpho- ecological groupings (Bouche, 1977). Epigeic species live in organic horizons and ingest large amounts of undecomposed litter. These species produce ephemeral burrows into the mineral soil for diapause periods only. They are relatively exposed to climatic fluctuations and predator pressures, and tend to be small with rapid generation times. A common example is Eisenia foetida (redworm, manure worm) which is used in vermicomposting.

Endogeic species forage below the surface, ingest large quantities of soil with a preference towards organic rich soil, and build continuously ramifying burrows that are mostly horizontal. These species are apparently not of major importance in litter incorporation and decomposition since they feed on subsurface material.

They are important in other soil formation processes including root decomposition, soil mixing, and aeration.
Species which build permanent, vertical burrows that penetrate the soil deeply were termed anecics by Bouche. These species are detritivores and come to the surface to feed on partially decomposed litter, manure, and other organic matter. The permanent burrows of anecics create a microclimatic gradient, and the earthworms can be found shallow or deep in their burrows depending on the prevailing conditions. Anecics have profound effects on organic matter decomposition, nutrient cycling, and soil formation. The most common examples are the nightcrawlers sold by fish-bait dealers consisting of Lumbricus terrestris and Aporrectodea longa.

Palatability of different types of litter to earthworms may depend on nitrogen and carbohydrate content, and the presence of polyphenolics such as tannins (Satchell, 1967). Earthworms prefer materials with a low $\mathrm{C} / \mathrm{N}$ ratio, such as clovers, to grasses which have a higher $\mathrm{C} / \mathrm{N}$ ratio (Ruz Jerez et al., 1988). Colonization of litter residues by microorganisms also increases palatability (Cortez et al., 1989), as does leaching of feeding inhibitors. 


\section{Epigeic: surface dwellers}

Epigeic earthworms live in areas containing high amounts of organic matter. They live at or near the soil surface and feed on leaf litter, decaying plant roots or dung. These earthworms do not form permanent burrows. Epigeic species tend to have dark skin colour (pigmentation). The pigmentation acts as camouflage as they move through the leaf litter.

It also helps to protect them from UV rays. Being close to the ground surface exposes the earthworms to predators so their muscles are strong and thick in proportion to their length, allowing for quick movement. Being so close to the surface also makes them vulnerable to stock treading in intensively grazed paddocks.

Epigeic species tend to be small $(1-18 \mathrm{~cm}$ in length). Introduced epigeic earthworms tend to live in compost (such as the introduced tiger worm Eisenia fetida, which cannot survive in soil) and under logs and dung. Native species usually live in forest litter.

\section{Endogeic: top-soil -dwellers}

Endogeic earthworms are the most common earthworm species found in New Zealand. Their niche is the top $20 \mathrm{~cm}$ depth of soil. Endogeic earthworms eat large amounts of soil and the organic matter in it, although species sometimes come to the surface to search for food.

They form shallow semi-permanent burrows. Endogeic earthworms have some pigmentation. Their muscle layers are not as thick nor do they move as quickly as epigeic earthworms. Endogeic species range in size from 2.5-30 $\mathrm{cm}$. Introduced endogeic earthworms are often found in agricultural soils, while native endogeic earthworms are often found in tussock grasslands.

\section{Anecic: subsoil dwellers}

Anecic earthworms live in permanent burrows as deep as $3 \mathrm{~m}$ below the soil surface. They collect food from the soil surface and ingest organic matter from the soil. Anecic earthworms form extensive burrows that extend laterally and vertically through the subsoil. Their burrows can be up to $2 \mathrm{~cm}$ in diameter. Introduced anecic earthworms have some pigmentation. Indigenous anecic species tend to be sluggish and have weakly developed muscles. Because they live so deeply in the soil, native anecic species have little pigmentation, and being so pale, they are often referred to as milk worms. These deepburrowing species are also the longest, ranging from $3 \mathrm{~cm}$ up to a very large $1.4 \mathrm{~m}$.

\section{Treetop dwellers and other unusual habitats}

Earthworm habitats and niches are not all under the ground. Native earthworms are frequently found under the bark of dead trees, in the litter of epiphytes and sometimes in the crooks of tree branches! There are also a number of aquatic earthworms that live in semi-saturated habitats.

\section{Beneficial aspects of earthworms}

Deep burrowing species such as $L$. terrestris can burrow through compacted soil and penetrate plough pans, creating channels for drainage, aeration, and root growth (Joschko et al., 1989). Recent work by Shipitalo and Protz (1989) elucidated some of the mechanisms by which earthworms enhance soil aggregation. Ingested aggregates are broken up in a liquid slurry that mixes soil with organic material and binding agents. The defecated casts become stable after drying. Stewart et al., (1988) also presented evidence that earthworms initiate the formation of stable soil aggregates in land degraded by 
mining. In forest ecosystems earthworms, especially litter feeders such as L. terrestris, can consume all the litter deposited on the soil surface within a period of several weeks (Knollenberg et al., 1985) or months (Satchell, 1967). Incorporation of litter by earthworms in apple orchards can be an important mechanism for preventing outbreaks of scab fungus, spores of which are transmitted from litter to new foliage by spring rains. Raw (1962) found a high correlation between L. terrestris biomass and apple leaf litter incorporation, with over 90 percent of litter incorporated during the winter when this species was abundant.

Incorporation of surface litter may be an important function of earthworms in notillage agroecosystems. Introduction of earthworms to areas not previously populated has led to improvement of soil quality and productivity in New Zealand grassland (Martin, 1977), on drained Dutch polders (Van Rhee, 1977), in heathland in Ireland (Curry and Bolger 1984), and in mining spoils in the U.S. (Vimmerstedt and Finney, 1973).

Earthworm casts are sources of nutrients for plants. Lumbricids in a pasture soil produced casts that contained 73 percent of the nitrogen found in the ingested litter; indicating both the importance of earthworms in incorporating litter nitrogen into the soil and the inefficiency of nitrogen digestion by earthworms (Syers et al., 1979). Earthworms increase the amount of nitrogen mineralized from organic matter in soil. Because nitrification is enhanced in earthworm casts, the ratio of nitrate- $\mathrm{N}$ to ammonium- $\mathrm{N}$ tends to increase when earthworms are present (Ruz Jerez et al., 1988). Nitrogen-fixing bacteria are found in the gut of earthworms and in earthworm casts, and higher nitrogenase activity, meaning greater rates of $\mathrm{N}$-fixation, are found in casts when compared with soil (Simek and Pizl, 1989).
Earthworms may increase levels of metabolic activity in soils, as measured by the amount of $\mathrm{CO} 2$ evolved, yet nematode abundance and microbial biomass may decrease (Yeates, 1981; Ruz Jerez et al., 1988). This occurs because earthworms reduce the amount of substrate available to other decomposers, and because earthworms ingest other decomposer organisms as they feed. This process would tend to accelerate nutrient cycling rates.

\section{Management effects on earthworms}

Earthworms are not favored by tillage, and in general the greater the intensity and frequency of disturbance, the lower the population density or biomass of earthworms (Haukka, 1988; Mackay and Kladivko 1985; Edwards, 1980; Gerard and Hay, 1979; Barnes and Ellis, 1979). Agricultural soils are generally dominated by species adapted to disturbance, low organic matter content, and a lack of surface litter. Earthworms are dependent on moderate soil moisture content, and cultivation tends to have a negative effect on earthworms by decreasing soil moisture (Zicsi, 1969). Some common agricultural lumbricids are Allolobophora chlorotica, the Aporrectodea caliginosa species complex (A. trapezoides, A. turgida, and A. tuberculata), and L. terrestris. Species common to organic rich habitats, such as E. foetida are rarely found (Lee, 1985).

Earthworm populations are usually significantly depressed in cropped fields relative to pasture or undisturbed lands. Lumbricids in a South African soil were decreased by cultivation to about one-third of original levels. Aporrectodea trapezoides was less affected than Eisenia rosea, possibly because it is able to burrow more deeply in the soil and escape the zone of disturbance (Reinecke and Visser; 1980). Gerard and Hay (1979) reported 93 earthworms per square meter in normally plowed plots, including $A$. 
caliginosa, A. chlorotica, A. longa, and $L$. terrestris. Earthworm abundance increased in plots that received disk cultivation, or no-till treatment Earthworm abundance doubled in no-till soybeans as compared with plowing (Mackay and Kladivko, 1985).

The major function of tillage is to decrease bulk density of soil and increase porosity, it only increases microporosity. Macropores, which may be of physical or biological origin and which can play an important role in conducting water rapidly into the soil, are destroyed by tillage. For instance, a 67 percent decrease in the rate of infiltration after plowing a tropical forest soil was attributed to the destruction of earthworm burrows.

Infiltration in an adjacent arable soil, which was initially much lower than in the forest soil, increased by 23 percent after plowing because the surface crust was broken (Aina, 1984). Infiltration increases in cropped soils when an organic mulch is added in the fall, due to the increased activities of earthworms in these soils and the production of macropores (Slater and Hopp, 1947). Soil compaction caused by agricultural traffic can also decrease earthworm populations (Bostrom, 1986).

A study in Denmark found that $200 \mathrm{~T} / \mathrm{ha}$ of manure was optimal for increased earthworm abundance and biomass (Andersen, 1980). $L$. terrestris, A. longa, and A. caliginosa were increased by manure, while $A$. rosea and $A$. chlorotica were not influenced The Rothamsted Experiment Station plots in England which received manure for 118 years also had increased earthworm abundance, and inorganic fertilizers in this case caused decreases in earthworm populations (Edwards and Lofty, 1974). Heavy applications of inorganic fertilizers may cause immediate reductions in earthworm abundance (Edwards, 1983).
Organic mulches enhance earthworm habitat by moderating microclimate and supplying a food source. In corn plots in Pennsylvania, earthworms were most abundant in the fall in treatments that were not plowed before winter and where corn residues had been chopped and left as a mulch, regardless of whether the plots were organically or conventionally managed (Werner and Dindal, 1990).

Effects of agricultural pesticides on earthworms depend on the chemical used. Herbicides tend to have low toxicity for earthworms, but can cause population reductions by decreasing organic matter input and cover from weed plants. Fungicides and fumigants tend to be very toxic to earthworms. Application methods may have unique effects on ecological groups of soil animals. For instance, the fungicide benomyl caused reductions of field populations of earthworms. Anecics such as L. terrestriswere most susceptible to surface applications, and were less affected by incorporation of the pesticide into the soil. Because L. terrestris forms permanent burrows, it does not come into contact with subsurface soil beyond its burrow. However; endogeic species such as A. caliginosa, which continuously extend their burrows as they feed in the subsurface soil, were most susceptible when benomyl was incorporated (Edwards and Brown, 1982).

\section{Enhancing earthworm populations}

There are many creative ways in which a farmer can manage for earthworms. A first step might be to determine what earthworm ecotypes are present, and how abundant they are. Endogeic species are most commonly found. These are useful, but a mixed community including anecic species as well would be even more beneficial, especially for incorporation of surface matter. Direct inoculation is one possible method, but 
transferring blocks of soil (one cubic foot each) from an area with a large earthworm population into a farm soil might work better. It is also important to consider what species should be introduced, and this is where research specific to seasonally-dry climates in California is needed. Much of our knowledge about earthworms concerns species of one family, the Lumbricidae, which are native to moist temperate areas of Europe. The spread of these earthworms has paralleled European colonialism around the world. They are the only earthworms present in the northeastern US and Canada, where glaciation killed the native fauna. In areas that have a native earthworm fauna, lumbricids often dominate in disturbed habitats. Morphologically, lumbricids are more muscular than any other family of earthworms, suggesting a greater capacity for burrowing (Hartenstein, 1986).

The earthworm fauna in California includes some native species, lumbricid immigrants, as well as immigrants from Asia and South America. From limited personal observations, the lumbricids found in California agricultural soils tend to have small populations that are active for relatively short periods during the wet season. This may reflect agricultural management practices as well as climate effects. There may be species that are adapted to seasonally-dry climates that would flourish in California agricultural soils, if provided the proper conditions.

One management idea for introducing desired species is to set aside a small area of land on a farm to be managed exclusively as an earthworm reservoir. If needed, the soil could be limed to bring it near $\mathrm{pH} \mathrm{7,} \mathrm{fertilized,} \mathrm{and}$ a cover crop established and cut periodically to provide an organic mulch as food and physical cover. In this area a community of the desired species could be established and built up. From this reservoir blocks could periodically be taken and introduced into the field. Rate of spread would vary with species and conditions in the field. Lumbricus terrestris is capable of travelling at least 19 meters on the soil surface in the course of one evening foray (Mather and Christensen, 1988). This is a long term process for establishing earthworms, and would only be successful if ample organic matter was supplied to the soil where earthworms were being introduced, and if physical and chemical disturbances of the soil were minimized. Organically managed perennial crops would be ideal for this method.

\section{Future challenges in earthworm research and implications}

Earthworms play an important role in soil processes and affect ecosystem services essential for human well-being (Skubala, 2013). These organisms have significant ecological functions in areas with agricultural land use, but their existence is very sensitive to disturbances caused by anthropogenic activities that threaten biodiversity. The impact of earthworm diversity and reduction of environmental services on agricultural productivity has been frequently discussed at various stakeholder levels, but serious actions have not been undertaken before (Van Noordwijk and Swift, 1999). That is because the level of public understanding of benefits provided by biodiversity is still inadequate (Van Noordwijk and Hairiah, 2006). The important role of the earthworm biodiversity in environmental services and human wellbeing needs to be disseminated to all parties. Quantitative data showing the evidence of earthworms role in ecological services and their benefits to human well-being need to be communicated to public.

Dissemination of knowledge on earthworm diversity conservation to farmers needs to be prioritized because they are the direct "actors" in agricultural activities. The level of farmers' 
knowledge about earthworms and their benefits in agricultural land varies depending on gender, education level, and age of farmers (Zúñiga et al., 2013). Such scientific knowledge on the importance of earthworm diversity in soils needs to be imparted in languages easily understood by farmers. The entry point of communication between scientists and farmers is to obtain local knowledge that farmers have about earthworms. For examples, what is their perception of earthworms in their land, how many types of earthworms farmers observe, whether earthworms have a different roles, where they prefer to live in deep soil, and what are their characteristics. Such questions can be used by scientists to determine what farmers know about earthworms. This knowledge can be used to develop proposals for earthworm diversity conservation and rural development.

Not all earthworms have the same function in soil processes. Which species plays an important role in ecosystems services? How many ecosystem services can be restored and how? Studies on earthworm diversity are indispensable. The study of key species and redundancy of ecosystem processes are necessary. Understanding the mechanisms underlying the survival of earthworm species in agroecosystems and protected areas can help to develop biodiversity conservation strategies (Zúñiga et al., 2013). Diversity of earthworms is highly sensitive to land use changes and human activities. The estimation of earthworm species richness, abundance, and biomass represents the potential tool to evaluating land management practices and soil ecosystem services.

What questions scientific research should address to achieve an accurate estimation of earthworm diversity threats and essential ecosystem services? To study the diversity of earthworms in different parts of the world, it is necessary for earthworm experts to train inexperienced earthworm taxonomists. Thus, comprehensive earthworm identification keys that can be used worldwide need to be made available. Influence of earthworms on soil processes and ecosystem services is the result of not only earthworm activities but also earthworm interaction with other organisms and environmental factors related to human activities. Hence, future research should be directed to study the relationships between earthworms, other factors in order to improve ecosystems services beneficial to human welfare. A good understanding of species performance within different functional groups in relation to environmental services is necessary to develop land management practices having a positive impact on environmental services.

Agricultural management practices oriented to sustainable production, such as reduced tillage, minimum tillage, legume cover crop, mixed farming, and green manuring, should be applied to soil biota. The quality of soil must be preserved or restored if it provides crucial services, such as nutrient cycling, water, air, and supports biodiversity.

\section{Acknowledgement}

Present attempt on "Ecosystem Services of the Eco-engineers: the Earthworms" is the part of Environmental Science Project for S. Y. B. Sc. (Academic Year: 2018 - 2019) submitted by Mansi Ramesh Das; Amruta Chandrakant Nimbalkar and Samiksha Sunil Pisal to Savitribai Phule Pune University, Pune through Science Association, Shardabai Pawar Mahila Mahavidyalaya, Shardanagar. Authors are highly grateful to Agriculture Development Trust, Shardanagar (Baramati) for valuable help, providing facilities at the Malegaon sheti farm \& laboratory facilities at Shardabai Pawar Mahila College to carry out the experimentations. 


\section{References}

Aina, P.Q. 1984. Contribution of earthworms to porosity and water infiltration in a tropical soil under forest and long-term cultivation. Pedobiologia 26(2): 131136.

Andersen, C. 1980. The influence of farmyard manure and slurry on the earthworm population (Lumbricidae) in arable soil. In: Dindal, D.L. (ed.). Soil Biology as Related to Land Use Practices. EPA, Washington, DC. pp. 325-335.

Asuming-Brempong $\mathrm{S}$ and Nyalemegbe KK (2014) The use of earthworms and biochar to mitigate an increase in nitrous oxide production - A mini review. Glob. Adv. Res. J. Agricul. Sci., 3: 35-41.

Barnes, B.T., F.B. Ellis. 1979. Effects of different methods of cultivation and direct drilling and disposal of straw residues on populations of earthworms. J Soil Sci. 30:669-679.

Black HIJ, Hornung M, Bruneau PMC, Gordon JE, Hopkins JJ, Weighell AJ and Williams DLI (2003) Soil biodiversity indicators for agricultural land: Nature conservation perspectives. In: Agricultural Impacts on Soil Erosion and Soil Biodiversity: Developing indicators for analysis policy (Francaviglia R, ed.). pp. 517-533. Proceedings from OECD Expert Meeting Rome, Italy.

Blanchart E, Albrecht A, Alegre J, Duboisset A, Gilot C, Pashanasi B, Lavelle P and Brussaard L (1999) Effects of earthworms on soil structure and physical properties. In: Earthworm Management in Tropical Agroecosystems. (Lavelle P, Brusaard L and Hendrix P, eds.). pp. 149-172. CAB International. Wallingford. UK.

Blouin M, Hodson ME, Delgado EA, Baker G, Brussaard L, Butt KR, Dai J,
Dendoovenh L, Peres G, Tondoh JE, Cluzeau D and Brun JJ (2013) A review of earthworm impact on soil function and ecosystem services. Eur. J. Soil Sci., 64: 161-182.

Bostrom, U. 1986. The effect of soil compaction on earthworms (Lumbricidae) in a heavy clay soil. Swedish J. Agric. Res. 16:137-141.

Bouche, M.B. 1977. Strategies lombriciennes. In: Lohm, U. and T. Persson (eds.). Soil Organisms as Components of Ecosystems. Biol. Bull. (Stockholm) 25:122-132.

Boyer S and Wratten SD (2010) The potential of earthworms to restore ecosystem services after opencast mining - a review. Bas. Appl. Ecol., 11: 196-203.

Breure AM (2004) Soil Biodiversity: Measurement, indicator, threats and soil functions. International Conference Soil and Compost Eco-Biology September 15th-17th, Leon Spain.

Brown GG, Callaham Jr. MA, Niva CC, Feijoo A, Sautter KD, James SW, Fragoso C, Pasini A and Schmelz RM (2013) Terrestrial oligochaete research in Latin America: The importance of the Latin American meetings on oligochaete ecology and taxonomy. Appl. Soil Ecol., 69: 2-12.

Brown GG, Feller C, Blanchart E, Deleporte P and Sergey SC (2003) With Darwin, earthworms turn intelligent and become human friends. Pedobiologia, 47: 924933.

Brown GG, Fragoso C and James SW (2006) Earthworm biodiversity in Latin America: Present state of the art. Guide book of the 8th International Symposium on Earthworm Ecology, Kraków, Poland.

Brusaard L (1997) Biodiversity and ecosystem functioning in soil. Ambio, 26: 563-570. 
Brussaard L, Hauser S and Tian G (1993) Soil faunal activity in relation to sustainability of agricultural systems in the humid tropics. In: Soil Organic Matter Dynamics and Sustainability of Tropical Agriculture (Mulongoy K and Merck R, eds.). pp. 241-256. John Wiley \& Sons Ltd. United Kingdom.

Bullock C, Kretsch C and Candon E (2008) The Economic and Social Aspects of Biodiversity in Ireland. The Stationary Office, Government of Ireland.

Cang CH and James S (2011) A critique of earthworm molecular phylogenetics. Pedobiologia, 54: S3-S9.

Capowiez Y, Monestiez P and Belzunces L (2001) Burrow systems made by Aporrectodea nocturna and Allolobophora chlorotica in artificial cores: Morphological differences and effects of interspecific interactions. Appl. Soil Ecol., 16: 109-120.

Chandran MSS, Sujatha S, Mohan M, Julka JM and Ramasamy EV (2012) Earthworm diversity at Nilgiri biosphere reserve, Western Ghats, India. Biodivers. Conserv., 21: 33433353.

Cortez, J., R. Hameed and M.B. Bouche. 1989. $\mathrm{C}$ and $\mathrm{N}$ transfer in soil with or without earthworms fed with $14 \mathrm{C}$ and $15 \mathrm{~N}$-labelled wheat straw. Soil Biol. Biochem. 21(4):491- 497.

Costanza R, d'Arge R, de Groot R, Farberk S, Grasso M, Hannon B, Limburg K, Naeem S, O'Neill RV, Paruelo J, Raskin RG, Suttonkk $P$ and van den Belt $M$ (1997) The value of the world's ecosystem services and natural capital. Nature, 387: 253-260.

Crossman ND, Burkhard B, Nedkov S, Willemen L, Petz K, Palomo I, Drakou EG, Martín-Lopez B, McPhearson T, Boyanova K, Alkemade R, Egoh B, Dunbard MB and Maes J (2013) A blueprint for mapping and modelling ecosystem services. Ecosystem Services, 4: 4-14.

Curry, J.P. and T. Bolger. 1984. Growth, reproduction and litter and soil consumption by Lumbricus terrestris in reclaimed peat. Soil Biol. Biochem. 16:253-257.

De Groot RS, Wilson MA and Boumans RMJ (2002) A typology for the classification, description and valuation of ecosystem functions, goods, and services. Ecol. Econ., 41: 393-408.

De Vriesa FT, Thébault E, Liiri M, Birkhofer K, Tsiafouli MA, Bjørnlund L, Jørgensen HB, Brady MV, Christensen S, de Ruiter PC, d'Hertefeldt T, Frouz J, Hedlund K, Hemerik L, Hol WHG, Hotes S, Mortimer SR, Setälä $H$, Sgardelis SP, Uteseny K, van der Putten WH, Wolter V and Bardgett RD (2013) Soil food web properties explain ecosystem services across European land use systems. Proc. Natl. Acad. Sci. USA, 110: 14296-14301.

Dewi WS, Hairiah K, Yanuwiyadi B and dan Suprayogo D (2006) Can agro-forestry systems maintain earthworm diversity after conversion of forest to agricultural land? Agivita, 28: 198-220.

Dewi WS, Hairiah K, Yanuwiyadi B dan Suprayogo D (2007) Dampak Alih Guna Hutan Menjadi Lahan Pertanian: Perubahan diversitas cacing tanah dan fungsinya dalam mempertahankan pori makro tanah. Disertasi Program Doktor Ilmu-ilmu Pertanian. Universitas Brawijaya. Malang, Indonesia.

Doran, J.D. and M.R. Werner. 1990. Management and soil biology. In: Francis, C.A., C.B. Flora and L.D. King (eds.). Sustainable Agriculture in Temperate Regions. Wiley. New York, NY pp. 205-230.

Dupont L (2009) Perspectives on the application of molecular genetic to 
earthworm ecology. Pedobiologia, 52: 191-205.

Edwards CA and Lofty JR (1977) Biology of Earthworms. Chapman and Hall. London.

Edwards, C.A. 1983. Earthworm ecology in cultivated soils. In: Satchell, J.E. (ed.). Earthworm Ecology from Darwin to Vermiculture. Chapman and Hall. London. pp.123-138.

Edwards, C.A. and J.R. Lofty. 1974. The invertebrate fauna of the Park Grass plots: I. Soil fauna Rothamsted Report, 1974. Part 2:133-154.

Edwards, P.J. and S.M. Brown. 1982. Use of grassland plots to study the effects of pesticides on earthworms. Pedobiologia 24:145-150.

Eisenhauer N and Schädler M (2011) Inconsistent impacts of decomposer diversity on the stability of aboveground and belowground ecosystem functions. Oecologia, 165: 403-415.

Elmer WH (2012) Using earthworms to improve soil health and suppress diseases. The Connecticut Agriculture Experiment Station. www.ct.gov/cae

Ernst G and Emmerling C (2009) Impact of five different tillage systems on soil organic carbon content and the density, biomass and community composition of earthworms after a ten-year period. Eur. J. Soil Biol., 45: 247-251.

Fragoso C and Csuzdi C (2004) Internal and External Morphology of Earthworms. Earthworms Training Material. Nairobi, Kenya.

Fragoso C and Lavelle P (1995) Are earthworms important in the decomposition of tropical litter? In: Soil Organisms and Litter Decomposition in Tropics (Reddy MV, ed.) pp. 103-112. Oxford \& IBH Publishing Co. New Delhi.
Fragoso C, Brown GG, Patron JC, Blanchart E, Lavelle P, Pashanasi B, Senapati B and Kumar T (1997) Agricultural intensification, soil biodiversity and agro-ecosystem function in the tropics: The role of earthworms. Appl. Soil Ecol., 6: 17-35.

Fragoso C, Kanyonyo J, Moreno A, Senapati BK, Blanchart $\mathrm{E}$ and Rodriguez C (1999). A survey of tropical earthworms: Taxonomy, biogeography, and environmental Plasticity. In: Earthworms Management in Tropical Agroecosystems (Lavelle P, Brussaard $\mathrm{L}$ and Hendrix P, eds.). pp. 1-26. CAB International. Wallingford, UK.

Gerard, B.M. and R.K.M. Hay. 1979. The effect on earthworms of ploughing, tined cultivation, direct drilling and nitrogen in a barley monoculture system. J. Agric. Sci. Cambridge 93: $147-155$.

Giller KE, Beare MH, Lavelle P, Izac AMN and Swift MJ (1997) Agriculture intensification, soil biodiversity, and agroecosystem function. Appl. Soil Ecol., 6: 3-16.

Glinski J and Lipiec J (1990) Soil Physical Conditions and Plant Roots. Boca Raton (Florida): CRC Press, Inc. 250 p.

González G, Huang CY, Zou X and Rodriquez C (2006). Earthworms invasions in the tropics. Biol. Invasions, 8: $1247-1256$.

Hairiah K, Swibawa IG, Dewi WS, Aini FK, Suprayogo D, Susilo FX and Van Noordwijk M (2014) Shade, litter, nematodes, earthworms, termites and companion trees in coffee agroforestry in relation to climate resilience. Abstract of World Congress on Agroforestry. 10-14 February 2014 Delhi, India.

Hartenstein, R. 1986. Earthworm biotechnology and global 
biogeochemistry. Adv. Ecol. Res. 15:379- 409 .

Haukka, J. 1988. Effect of various cultivation earthworm biomasses and communities on different soil types. Ann. Agric. Fenniae 27:263-269

Hendrix PF and Bohlen PJ (2002) Exotic earthworm invasion in North America: Ecological and policy. BioScience, 52: 801-811.

http://www.agrsci.jp/ras/article/view/13/27

Hunter Jr. M (1999) Biological diversity. In: Maintaining Biodiversity in Forest Ecosystems. (Hunter Jr M, ed.). pp. 321.Cambridge University Press. Cambridge, UK.

Jeffery S and Gardi C (2010) Soil biodiversity under threat - a review. Acta Soc. Zool. Bohemia., 74: 7-12.

Jiménez JJ, Moreno AG, Decaens T, Lavelle P, Fisher MJ and Thomas RJ (1998) Earthworms communities in native savannas and man-made pastures of the eastern plains of Colombia. Biol. Fertil. Soils, 28:101-110.

Jones DT (2003) Introduction to earthworms. The course on tools for monitoring soil biodiversity in the ASEAN region at Universiti Malaysia Sabah, Kota Kinabalu, from 12-16 Oct. 2003. Universiti Malaysia Sabah.

Joschko, M., H. Diestel and O. Larink. 1989. Assessment of earthworm burrowing efficiency in compacted soil with a combination of morphological and soil physical measurements. Biol. Fert. Soils 8:191- 196.

Jouquet P, Blancart E and Capowiez Y (2014) Utilization of earthworms and termites for the restoration ecosystem functioning. Appl. Soil Ecol., 73: 34-40.

Keith AM and Robinson DA (2012) Earthworms as natural capital: Ecosystem service providers in agricultural soils. Economology Journal II: 91-99.
Kibblewhite MG, Ritz K and Swift MJ (2008) Soil health in agricultural systems. Phil. Trans. R. Soc. B., 363: 685-701.

Kladivko, E.J. and H.J. Timmenga. 1990. Earthworms and agricultural management. In: Box, J.E. and L.C. Hammond (eds.). Rhizosphere Dynamics. Westview Press. CO. Kladivko, E.J., AD. Mackay and J.M. Bradford 1986. Earthworms as a factor in the reduction of soil crusting. Soil Sci. Soc. Am. J. 50:191-196.

Knollenberg, W.G., R.W. Merritt, and D.L. Lawson. 1985. Consumption of leaf litter by Lumbricus terrestris (Oligochaeta) on a Michigan woodland floodplain. Am. Midl. Nat. 113(1):1-6.

Lal R (1991) Soil conservation and biodiversity. In: The Biodiversity of Microorganisms and Invertebrates: Its role in sustainable agriculture (Hawksworth DL, ed.). pp. 73-87. Proceedings of the First Workshop on Ecological Foundations of Sustainable Agriculture (WEFSA I), London, 26-27 July 1990. CAB International Pub. UK.

Lavelle P (2000) Ecological challenges for soil science. Soil Sci., 165: 73-86.

Lavelle P (2009) Ecology and the challenge of multifunctional use of soil. Pesq. Agropec. Bras., Brasilia, 44: 803-810.

Lavelle P and Spain AV (2001) Soil Ecology. Kluwer Academic Publ., Dordrecht.

Lavelle P, Barros E, Blanchart E, Brown G, Desjardins T, Mariani L and Rossi J-P (2001) SOM management in the tropics: Why feeding the soil macrofauna? Nutrient Cycling in Agroecosystems, 61: 53-61.

Lavelle P, Decaëns T, Aubert M, Barot S, Blouin M, Bureau F, Margerie P, Mora $P$ and Rossi J-P (2006) Soil invertebrates and ecosystem services. European J. Soil Biol., 42: S3-S15. 
Lee KE (1985) Earthworms, Their Ecology and Relationships with Soils and Land Use. Academic Press. London.

Lee, K.E. 1985. Earthworms, their ecology and relationships with soils and land use. Academic Press. New York, NY.

Lofs-Holmin, A. 1983. Earthworm population dynamics in different agricultural rotations. In: Satchell, J.E. (ed.). Earthworm Ecology from Darwin to Vermiculture. Chapman and Hall. London. pp. 151-160.

Loss SR, Niemi GJ and Blair RB (2012) Invasions of non-native earthworms related to population declines of ground-nesting songbirds across a regional extent in northern hardwood forests of North America. Landscape Ecol., 27: 683-696.

Lubbers IM, Brussaard L, Otten W and Van Groenigen JW (2011) Earthworminduced $\mathrm{N}$ mineralization in fertilized grassland increases both $\mathrm{N} 2 \mathrm{O}$ emission and crop-N uptake. Eur. J. Soil Sci., 62: 152-161.

Lubbers IM, Van Groenigen KJ, Fonte SJ, Six $\mathrm{J}$, Brussaard L and Van Groenigen JW (2013) Greenhouse-gas emissions from soils increased by earthworms. Nature Climate Change, 3: 187-194.

Mackay, A.D. and E.J. Kladivko. 1985. Earthworms and rate of breakdown of soybean and maize residues in soil. Soil Biol. Biochem. 17(6):851-857.

Martin, N.A. 1977. Guide to the lumbricid earthworms of New Zealand pastures. New Zealand J. Exp. Agric. 5:301-309.

Mather, J.G. and O. Christensen. 1988. Surface movements of earthworms in agricultural land Pedobiologia 32:399405.

Moore BA (2005) Alien Invasive Species: Impacts on forests and forestry. Forest Health and Biosecurity Working Paper 8. FAO Corporate Document Repository.
Moreira FMS, Huising EJ and Bignell DE (2008). A Hand Book of Tropical Soil Biology Sampling and Characterization of Below-ground Biodiversity. Earthscan. United Kingdom.

Plaza-Bonilla P, Cantero-Martínez C and Álvaro-Fuentes J (2014) Soil management effects on greenhouse gasses production at the macro aggregate scale. Soil Biol. Biochem., 68: 471-481.

Rao SV (2013) Different Land Use Effect on Earthworms at SAFE Project Site in Sabah, Borneo. MSc. Thesis. Nottingham Trent University.

Raw, F. 1962. Studies of earthworm populations in orchards. I. Leaf burial in apple orchards. Ann. Appl. Biol. 50:389-404.

Reinecke, A.J. and F.A. Visser. 1980. The influence of agricultural land use practices on the population density of Allolobophora trapezoides and Eisenia rosea (Oligochaeta) in Southern Africa. In: Dindal, D.L. (ed.). Soil Biology as Related to Land Use Practices. EPA Washington, DC. pp. 310-324.

Ruz Jerez, E., P.R. Ball and R.W. Tillman. 1988. The role of earthworms in nitrogen release from herbage residues. In: Jenkinson, D.S. and K.A. Smith (eds.). Nitrogen Efficiency in Agricultural Soils. (publisher unknown) pp. 355-370.

Satchell, J.E. 1967. Lumbricidae. In: Burges, A. and F. Raw (eds.). Soil Biology. Academic Press. New York, NY. pp. 259- 322.

Satchell, J.E. 1983. Earthworm Ecology from Darwin to Vermiculture. Chapman and Hall. London.

Science for Environment Policy (2009) Deep ploughing reduces diversity and number of earthworms. Science for Environment Policy. Special Issue 14. 
Secretariat of the Convention on Biological Diversity (2010) Global Biodiversity Outlook 3. Montréal.

Shipitalo, M.J. and R. Protz. 1989. Chemistry and micromorphology of aggregation in earthworm casts. Geoderma 45:357374.

Simek M and Pizl V (2010) Soil CO2 flux affected by Aporrectodea caliginosa earthworms. Cent. Eur. J. Biol., 5: 364370.

Simek, M. and V. Pizl. 1989. The effect of earthworms (Lumbricidae) on nitrogenase soil. Biol. Fert. Soils 7:370373.

Sinha MP, Srivastava R and Gupta DK (2013) Earthworm biodiversity of Jharkhand: Taxonomic description. The Bioscan, 8: 293-310.

Skubała P (2013) Biodiversity and ecosystem services in soil under threat. J. Pollut. Eff. Cont. 1: e101.

Slater, C.S. and R. Hopp. 1947. Relation of fall protection to earthworm populations and soil physical conditions. Soil Sci. Soc. Am. Proc. 12:508-511.

Stewart, V.I., J. Scullion, R.O. Salih and K.H. Al Bakri. 1988. Earthworms and structure rehabilitation in subsoils and in topsoils affected by opencast mining for coal. Biol. Agric. Hort. 5:325-338.

Stott DE, Kennedy AC and Cambardella CA (1999) Impact of soil organisms and organic matter on soil structure. In: Soil Quality and Soil Erosion (Lal R, ed). pp. 57-74. Soil and Water Conservation Society. CRC Press. Washington DC.

Susilo FX, Murwani S, Dewi WS and Aini FK (2009) Effect of land use intensity on diversity and abundance of soil insects and earthworms in Sumberjaya, Lampung. Biospecies, 2: 1-11.

Suthar S (2011) Earthworm biodiversity in western arid and semiarid lands of India. Environmentalist, 31:74-86.
Syers, J.K., A.N. Sharpley, and D.R. Keeney. 1979. Cycling of nitrogen by surfacecasting earthworms in a pasture ecosystem. Soil Biol. Biochem. 11:181185.

Tian G (1992) Biological effects of plant residues with contrasting chemical compositions on plant and soil under humid tropical conditions. Ph.D. Thesis. Wageningen Agricultural University, The Netherlands.

Tondoh JE, Monin LM, Tiho S and Csuzdi C (2007) Can earthworms be used as bioindicators of land-use perturbations in semi-deciduous forest? Biol. Fertil. Soils, 43: 585-592.

USDA Forest Service International Programs (2014) Addressing the four threats in an international context land use conversion. http://www.fs.fed.us/global/ aboutus/policy/tt/reports/4threats/conver sion.pdf. Download August 27th, 2014.

Van Noordwijk M and Swift MJ (1999) Belowground biodiversity and sustainability of complex agroecosystems. In: Proceedings of the Workshop on Management of Agrobiodiversity in Indonesia for Sustainable Land Use and Global Environmental Benefits (Gafur A, Susilo FX, Utomo $M$ and Van Noordwijk M, eds.). pp. 8- 28. Unila/Puslibangtan, Bogor, 19-20 August 1999.

Van Noordwijk M dan Hairiah K (2006) Intensifikasi pertanian, biodiversitas tanah dan fungsi agro-ekosistem. Agrivita, 28: 185-197.

Van Rhee, J.A. 1977. A study of the effect of earthworms on orchard productivity. Pedobiologia 17:107-114.

Vimmerstedt, J.P. \& J.H. Finney. 1973. Impact of earthworm introduction on litter burial and nutrient distribution in Ohio stripmine spoil banks. Soil Sci. Soc Am. Proc. 37:388-391. 
Wardle DA (2002) Communities and ecosystems linking the aboveground and belowground components. Monograph in Population Biology. Princeton University Press. New Jersey.

Wardle DA, Bardgett RD, Klironomos JN, Setala H, Van der Putten WH and Hall DH (2004) Ecological linkages between aboveground and belowground biota. Science, 304: 1629-1633.

Werner, M.R. and D.L. Dindal. 1990. Earthworm community dynamics in conventional and low-input agroecosystems. Revue D'Ecologie et de Biologie du Sol 26(4):427-437.

Wolf B and Snyder GH (2003) Sustainable soil: The place of organic matter in sustaining soils and their productivity. Food products Press. New York.
Yeates, G.W. 1981. Soil nematode populations depressed in the presence of earthworms. Pedobiologia 22:191-195.

Zachmann, J.E. and D.R. Linden. 1989. Earthworm effects on corn residue breakdown and Infiltration. Soil Sci. Soc. Am. 53(6):1846-1849.

Zicsi, A. 1969. Uber die Auswirking der Nachfrucht und Bodenbearbeitung auf die Aktivitat der Regenwurmer. Pedobiologia 9:141-145 (Eng. summary).

Zúñiga MC, Feijoo MA, Quinterob H, Aldana NJ, Carvajal AF (2013) Farmers' perceptions of earthworms and their role in the soil. Appl. Soil Ecol., 69: 6168.341173 RAS-15-02.indd 35 2015/06/08 8:57:45.

\section{How to cite this article:}

Mansi Ramesh Das, Amruta Chandrakant Nimbalkar, Samiksha Sunil Pisal and Vitthalrao B. Khyade. 2018. Ecosystem Services of the Eco-Engineers: The Earthworms. Int.J.Curr.Microbiol.App.Sci. 7(10): 1065-1086. doi: https://doi.org/10.20546/ijcmas.2018.710.118 